\title{
'URF SEBAGAI METODE PENETAPAN HUKUM EKONOMI ISLAM
}

\author{
Khikmatun Amalia \\ khikmatunamalia85@gmail.com \\ IAIN Purwokerto
}

\begin{abstract}
This article aims to discuss matters related to 'urf as a method of determining Islamic economic law in economic activity. The research methodology in this article uses a qualitative method with a library research approach. The results showed that urf is something that is known and has become a community habit, either in the form of words or deeds. So that 'urf can be used as a method of determining Islamic economic law, including in economic transaction activities. Some examples of the application of 'urf in economic transactions today are buying and selling in modern shopping centers and online-based transactions without saying shighat (my words sell-I buy).
\end{abstract}

Keywords: 'Urf, Law, Islamic Economics.

\begin{abstract}
Abstrak
Artikel ini bertujuan untuk membahas hal-hal yang berkaitan dengan 'urf sebagai metode penetapan hukum ekonomi Islam dalam kegiatan perekonomian. Metodologi penelitian dalam artikel ini menggunakan metode kualitatif dengan pendekatan kepustakaan (library research). Hasil penelitian menunjukkan bahwa 'urf merupakan suatu hal yang dikenal dan sudah menjadi kebiasaan masyarkat, baik berupa ucapan ataupun perbuatan. Sehingga 'urf dapat dijadikan metode penetapan hukum ekonomi Islam termasuk dalam kegiatan transaksi ekonomi. Beberapa contoh penerapan 'urf dalam transaksi ekonomi sekarang ini adalah jual beli di pusat perbelanjaan modern dan transaksi yang berbasis online tanpa mengucapkan shighat (ucapan saya jual-saya beli). Dampak positif yang diharapkan dengan adanya artikel ini ialah masyarakat akan lebih bijak dalam bermuamalah serta mampu memanfaatkan teknologi sebagai dasar pembangunan bisnis yang amanah..
\end{abstract}

Kata Kunci: ’Urf, Hukum, Ekonomi Islam. 


\section{A. Pendahuluan}

Ada kalanya Alqur'an dan hadits tidak menjelaskan hukum Islam secara rinci, sementara ummat Islam harus menjalankan kehidupannya sesuai aturan, norma dan hukum Islam. Untuk menjawab "kegelisahan” tersebut, para ahli mengerahkan segenap kemampuan nalarnya guna mendapatkan solusi yang tepat pada setiap permasalahan yang ada. Inilah yang disebut ijtihad.Terdapat beberapa metode dalam berijtihad, di antaranya adalah istihsan, mashalih al-mursalah, istihshab, 'urf, syar'u man qablana.

Dalam kehidupan masyarakat banyak terdapat kebiasaan-kebiasaan atau tradisi yang populer secara luas di tengah kehidupan mereka.Tradisi tersebut dapat berupa perkataan atau perbuatan yang berlaku secara umum, hal semacam ini disebut dengan 'urf. Kebiasaan-kebiasaan tersebut dapat menjadi bahan pertimbangan ketika akan menetapkan hukum Islam dalam transaksi ekonomi yang semakin berkembang terutama terkait masalah-masalah yang tidak ada ketegasan hukum dalam al-Qur'an dan al-Hadits.Pembahasan adat kebiasaan sebagai 'urf di dalam ushul al-fiqh ditekankan pada kedudukannya sebagai suatu kepantasan yang telah dikenal secara luas oleh masyarakat.Dan'urf yang menjadi pertimbanganhukum Islam hanyalah'urf shahih saja. ..

\section{B. Pembahasan}

\section{Pengertian dan dasar hukum 'urf}

Sumber hukum Islam ada dua macam sumber yang 'tekstual' atau sumber tertulis yaitu langsung berdasarkan teks Al-Qur'an dan Sunnah Nabi. Dan yang kedua 'non tekstual' atau sumber tak tertulis seperti Ijma', Qiyas, Istishan,Mashalih al- Mursalah, Istishab,Urf', Syar'u Man Qablina, Mazhab Shahabi dan Zara'.2

Kedudukan dalil di kalangan para fuqaha ada yang disepakati dan ada yang di ikhtilafkan /diperdebatkan.Dalil yang disepakati di antaranya

1 Abdul Mun'im Saleh, Hubungan kerja Usul al-Fiqh dan al-Qawaid al-Fiqhiyah Sebagai Metode Hukum Islam (Yogyakarta: Nadi Pustaka, 2012), hlm:43. 
adalah Al-Qur'an, As-Sunnah, Ijma dan Qiyas. Sedangkan yag di ikhtilafkan adalah 'Urf, Syar’u manqablana, Madzhab Shahabi, Istishsan, Istishab, Maslahah Mursalah dan Sadd Dzariah. ${ }^{3}$

a. Pengertian ' $U r f$

Secara etimologi, 'urf berarti '’yang baik'.Atau 'sesuatu yang dipandang baik dan diterima oleh akal sehat'’.Sementara adat adalah sesuatu perbuatan yang dikerjakan secara berulang tanpa hubungan rasional. Dalam konteks ini, adat dan 'urf adalah sesuatu yang telah biasa berlaku, diterima dan dianggap baik oleh masyarakat. Secara terminology, 'urf didefinisikan sebagai kebiasaan mayoritas umat, baik dalam perkataan maupun perbuatan. Menurut Abdul Karim Zaidah, istilah 'urf berarti sesuatu yang telah dikenali oleh masyarakat dan merupakan kebiasaan dikalangan mereka, baik berupa perkataan, perbuatan, maupun pantangan-pantangan dan juga bisa disebut dengan adat.

Menurut istilah ahli syara', tidak ada perbedaan antara 'urf dan adat (adat kebiasaan).Namun dalam pemahaman biasa diartikan bahwa pengertian adat lebih umum dibanding dengan 'urf. Suatu kebiasaan dapat dikatakan sebagai 'urf jika memenuhi hal-hal berikut: pertama, kebiasaan itu harus disukai banyak orang. Kedua, kebiasaaan harus dilakukan secara berulang-ulang.Ketiga, kebiasaan itu harus popular dan dikenal oleh banyak komunitas. Ahmad Azhar Basyir menyebutkan tiga prasyarat 'urf lainnya,yaitu: pertama, adanya kemantapan jiwa. Kedua, sejalan dengan pertimbangan akal sehat.Ketiga, dapat diterima oleh watak pembawaan manusia.Oleh sebab itu, kebiasaan yang tidak memenuhi prasyarat tersebut tidak dapat dikatakan sebagai 'urf. ${ }^{4}$

Dalam hukum Islam, 'urf menempati posisi yang penting dalam penetapan hukum.Hal ini karena 'urf menjadi kebiasaan yang berlaku di masyarakat secara membudaya di tengah-tengah masyarakat. Oleh karena

2 Amir Syarifuddin, ' 'Ushul Fiqh 2'”, (Jakarta: Logos, 1999),hlm: 1

${ }^{3}$ Hasan Bisri, Model Penelitian Fiqh, (Bogor: Prenada Media, 2003), hlm: 49.

${ }^{4}$ Mohammad Mufid, Ushul Fiqh Ekonomi dan Keuangan Kontemporer,( Jakarta: PrenadaMedia Group,2016),hlm: 152 
itu, adat dan 'urf menjadi pertimbangan dalam menetapkan hukum yang telah dirumuskan menjadi kaidah umum, yaitu: al-adah muhakkamah dan al-Tsabit bi al-urfi ka al-Tsabit bi al-nash.

b. Dasar hukum 'urf pada surat Al-A'rof (17) ayat 199

Ayat Al-Qur'an yang artinya “Jadilah engkau pemaaf dan suruhlah orang mengerjakan yang makruf, serta berpalinglah daripada orang-orang bodoh” dan ucapan sahabat Rasulullah Saw Abdullah bin Mas’ud “sesuatu yang dinilai baik oleh kaum Muslimin adalah baik di sisi Allah dan sesuatu yang mereka nilai buruk maka ia buruk disisi Allah”.

Kebiasaan yang benar harus diperhatikan dalam pembentukan hukum syara' dan putusan perkara.Seorang mujtahid harus memperhatikan hal ini dalam pembentukan hukumnya dan bagi hakim juga harus memperhatikan hal itu dalam setiap putusannya. Karena apa yang sudah diketahui dan dibiasakan oleh manusia adalah menjadi kebutuhan mereka, disepakati danada kemaslahatannya. Adapaun adat yang rusak, maka tidak boleh diperhatikan, karena memperhatikan adat yang rusak berarti menentang dalil syara' atau membatalkan hukum syara'. Hukum yang didasarkan pada adat akan berubah seiring perubahan masalah asal. Oleh karena itu, dalam hal perbedaan pendapat ini para ulama fikih berkata:'perbedaan itu adalah waktu dan masa, bukan pada dalil dan alasan"’.

Suatu hukum yang ditetapkan atas dasar 'urf dapat berubah karena kumungkinan adanya perubahan 'urf itu sendiri atau perubahan tempat, zaman dan sebagainya.Sebagian mendasarkan hal itu pada kenyataan bahwa, Imam Syafi’i ketika di Irak mempunyai pendapat-pendapat yang berlainan dengan pendapat beliau sendiri setelah pindah ke Mesir.Di kalangan Ulama, pendapat Imam Syafi'i ketika di Irak disebut dengan qawl qadim, sedangkan pendapat di Mesir disebut qawl jaddid. Adapun alasan para Ulama yang memakai 'urf dalam menentukan hukum antara lain: Banyak hukum syariah yang ternyata sebelumnya telah menjadi 
kebiasaan orang Arab. Seperti adanya wali dalampernikahan.Dan transaksi jual beli tanpa sighat (tanpa menyebutkan akadnya) yang sudah sangat umum terjadi. ${ }^{5}$

\section{Macam-macam dan dasar hukum 'urf}

\section{A. Macam-macam 'Urf}

Para ulama ushul fiqh membagi 'urf kepada tiga macam:

1. Dari segi objeknya,'urf dibagi kepada:

a. Al-'urf al-lafzhi. adalah kebiasaan masyarakat dalam mempergunakan lafal/ungkapan tertentu dalam mengungkapkan sesuatu, sehingga makna itulah yang dipahami dan terlintas dalam pikiran masyarakat.

b. Al-urf al-'amali. Adalah kebiasaan masyarakat yang berkaitan dengan perbuatan biasa atau muamalah keperdataan,

2. Dari segi cakupannya,'urf terbagi dua yaitu

a. Al-'urf al-'am adalah kebiasaan tertentu yang berlaku secara luas di seluruh masyarakat dan di seluruh daerah.

b. Al-'urf al-khasadalah kebiasaan yang berlaku di daerah dan masyarakat tertentu.

3. Dari segi keabsahannya dari pandangan syara','urf terbagi dua:

a. Al-'urf al-shahih adalah kebiasaan yang berlaku di tengah-tengah masyarakat yang tidak bertentangan dengan nash (ayat atau hadist), tidak menghilangkan kemaslahatan mereka dan tidak pula membawa mudarat kepada mereka.

b. Al-'urf al-fasid adalah kebiasaan yang bertentangan dengan dalil-dalil syara' dan kaidah-kaidah dasar yang ada dalam syara'

\section{B. Kehujjahan 'Urf}

Para ulama ushul fiqh merumuskan kaidah-kaidah fiqh yang berkaitan dengan 'urf diantaranya adalah yang paling mendasar

${ }^{5}$ Rizal, Fitra, Penerapan ' 'Urf sebagai Metode dan Sumber Hukum Ekonomi Islam', Al-Manhaj: Vol. 1, No. 2 Juli 2019), hlm:161 


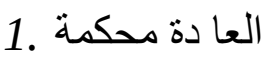

Adat kebiasaan itu bisa menjadi hukum

2. لا ينكر تغير الحكم بتغير الامكنة و الازمان

Tidak diingkari perubahan hukum disebabkan perubahan zaman dan tempat

3. المعروف عرفا كالثروط شرطا

Yang baik itu menjadi 'urf, sebagaimana yang disyaratkan itu menjadi syarat

Para ulama ushul fiqh menyatakan bahwa hukum-hukum yang didasarkan kepada 'urf bisa berubah sesuai dengan perubahan masyarakat pada zaman tertentu dan tempat tertentu.

\section{Syarat-Syarat 'Urf}

Para ulama ushul fiqh menyatakan bahwa suatu 'urf, baru dapat dijadikan sebagai salah satu dalil dalam menetapkan hukum syara' apabila memenuhi syarat-syarat sebagai berikut:

1. 'Urf itu (baik yang bersifat khusus dan umum maupun yang bersifat perbuatan dan ucapan), berlaku secara umum. Artinya: mayoritas kasus yang terjadi ditengah-tengah masyarakat dan keberlakuannya dianut oleh mayoritas masyarakat tersebut.

2. 'Urf itu telah memasyarakat ketika persoalan yang akan ditetapkan hukumnya itu muncul. Artinya 'urf yang dijadikan sandaran hukum itu lebih dahulu ada sebelum kasus yang akan ditetapkan hukumnya.

3. 'Urf itu tidak bertentangan dengan yang diungkapkan secara jelas dalam suatu transaksi. Artinya dalam suatu transaksi apabila kedua belah pihak telah menentukan secara jelas hal-hal yang harus dilakukan.

4. 'Urf itu tidak bertentangan dengan nash, sehingga menyebabkan hukum yang dikandung nash itu tidak bisa diterapkan. 


\section{Pertentangan 'Urf dengan dalil Syara'}

'Urf yang berlaku di tengah-tengah masyarakat adakalanya bertentangan dengan nash dan adakalanya bertentangan dengan dalil syara' lainya ${ }^{6}$. Dalam persoalan pertentangan 'urf dengan nash, para ahli ushul fiqh memerincinya sebagai berikut:

1. Pertentangan 'Urf dengan nash yang bersifat khusus/rinci.

Apabila pertentangan 'urf dengan nash khusus menyebabkan tidak berfungsinya hukum yang dikandung nash, maka 'urf tidak dapat diterima.

2. Pertentangan 'Urf dengan nash yang bersifat umum.

Menurut Mushthafa Ahmad al-Zarqa ', apabila 'urf telah ada ketika datangnya nash yang bersifat umum, maka harus dibedakan antara 'urf al-lafzhi dengan 'urf al-'amali. Apabila 'urftersebut adalah 'urf al-lafzhi, maka 'urf itu bisa diterima, sehingga nash yang umum itu dikhususkan sebatas 'urf al-lafzhi yang telah berlaku tersebut, dengan syarat tidak ada indikator yang menunjukkan bahwa nash umum itu tidak dapat dikhususkan oleh ' urf.

3. 'Urf yang terbentuk belakangan dari nash umum yang bertentangan dengan 'urf tersebut.

Apabila suatu 'urf terbentuk setelah datangnya nash yang bersifat umum dan antaranya keduanya terjadi pertentangan, maka seluruh ulama fiqh sepakat menyatakan bahwa 'urf seperti ini, baik yang bersifat lafzhi (ucapan) maupun yang bersifat 'amali (praktik), sekalipun 'urf itu bersifat umum, tidak dapat dijadikan dalil dalam menetapkan hukum syara', karena keberadaan 'urf ini muncul ketika nash syara' telah menentukan hukum secara umum. ${ }^{7}$

6 Turfaulmali M. Ikhfan, “Tradisi Mitoni dalam Perspektif Hukum Islam (Studi Kasus di Desa Laren Kecamatan Bumiayu Kabupaten Brebes)” (skripsi, IAIN Purwokerto, 2019), 20, http://repository.iainpurwokerto.ac.id/6573/; Adib Hamzawi, “Â€元rf Dalam Kompilasi Hukum Islam Indonesia,” INOVATIF: Jurnal Penelitian Pendidikan, Agama Dan Kebudayaan 4, no. 1 (2 Februari 2018): 56; Arini Rufaida, “Tradisi begalan dalam perkawinan adat Banyumas perspektif 'urf” (undergraduate, Universitas Islam Negeri Maulana Malik Ibrahim, 2011), 78, http://etheses.uin-malang.ac.id/1420/.

${ }^{7}$ Nasrun Haroen, Ushul Fiqh, (Jakarta: Logos,2001), hlm: 137-146 


\section{E. Kedudukan 'Urf dalam Menetapkan Hukum}

Secara umum 'Urf atau 'adat itu diamalkan oleh semua ulama fiqh terutama di kalangan ulama madzhab Hanafiyah dan Malikiyah.Ulama Hanafiyah menggunakan istihsan dalam berijtihad dan salah satu bentuk istihsan itu adalah al-'urf (istihsan yang menyandar pada 'urf). Oleh ulama Hanafiyah, 'Urf itu didahulukan atas qiyas khafi dan juga di dahulukan atas nash yang umum dalam arti 'Urf itu mentakhsis umum nash. Ulama Malikiyah menjadikan 'Urf atau tradisi yang hidup di kalangan ahli madinah sebagai dasar dalam menetapkan hukum dan mendahulukannya dari hadist ahad.Ulama Syafi'iyah banyak menggunakan 'Urf dalam hal-hal tidak menemukan ketentuan batasannya dalam syara maupun dalam penggunaan bahasa. Mereka mengemukakan kaidah sebagai berikut:

“Setiap yang datang dengannya syara' secara mutlak, dan tidak ada ukurannya dalam syara' maupun dalam bahasa, maka dikembalikan kepada 'Urf'

Dalam menanggapi adanya penggunaan 'Urf dalam fiqh, Al-Sayuti mengulasnya dengan mengembalikannya kepada kaidah:

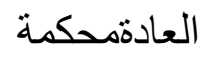

Para ulama yang mengamalkan 'Urf itu dalam memahami dan mengsitinbathkan hukum, menetapkan beberapa persyaratan untuk menerima 'Urf tersebut.

1. Adat atau 'Urf itu bernilai maslahat dan dapat diterima akal sehat

2. Adat atau ' $U r f$ itu berlaku umum dan merata di kalangan orang-orang yang berada dalam lingkungan 'adat itu atau dikalangan sebagian besar warganya.

3. Urf yang dijadikan sandaran dalam penetapan hukum itu telah ada (berlaku) pada saat itu bukan 'Urf yang muncul kemudian. 
4. Adat tidak bertentangan dan melalaikan dalil syara' yang ada atau bertentangan dengan prinsip yang pasti. ${ }^{8}$

\section{3. 'Urf sebagai Metode Penetapan Hukum Ekonomi Islam}

Islam sebagai system keyakinan (agama) pada satu sisi merupakan norma yang sangat personal. Adapun ekonomi sebagai suatu system merupakan kegiatan-kegiatan dan transaksi yang bersifat profite-motife, keinginan untuk mendapatkan keuntungan ${ }^{9}$. Namun jika melihat pada kandungan-kandungan ajaran yang diterangkan dalam islam sangat jelas nyata Islam tidak hanya sebagai system keyakinan (agama) tapi islam juga merupakan suatu sumber ajaran dari tatanan ekonomi. Ajaran tersebut di jelaskan secara tersuratataupun tersirat. ${ }^{10}$

Ahmad M.Saefudin sebagaimana dikutip oleh Mohammad Daud Ali dan Ridwan menyatakan bahwa ada tiga asas filsafat ekonomi Islam.Pertama, prinsip semua yang ada di alam semesta, langit, bumi serta sumber-sumber alam yang ada padanya, bahkan harta kekayaan yang dimiliki manusia adalah milik Allah sebagai sang pencipta. Semua ciptaan Allah tunduk pada kehendak dan ketentuan-ketentuan-Nya (QS,20:5). Asas ini telah meletakan masalah kepemilikan manusia sebagai kepemilikan yang relative dan Allah adalah pemilik yang sesungguhnya sebagai kepemilikan yang relative dan Allah adalah pemilik yang sesungguhnya. Kedua, prinsip Tauhid, bahwa Allah adalah Tuhan yang Esa. Prinsip ini memberikan makna bahwa manusia sebagai khalifah Allah di muka bumi harus mengelola semua fasilitas yang diberikan Allah untuk mengabdi kepada Tuhan yang satu yaitu Allah SWT sebagai poros aktifitas manusia. Ketiga, prinsip keimanan kepada hari akhir yaitu hari pembalasan amal perbuatan manusia dalam berbagai bentuk aktifitasnya

${ }^{8}$ Ibid, Amir Syarifudin,hlm: 374-377

9 Galuh Nashrullah Kartika Mayangsari Rofam, "Penerapan Konsep ’Urf dalam Kitab Sabilal Muhtadin (Kajian Terhadap Pemikiran Muhammad Arsyad Al-Banjari),” Al Iqtishadiyah Jurnal Ekonomi Syariah Dan Hukum Ekonomi Syariah 4, no. 1 (7 Desember 2018): 76, https://doi.org/10.31602/iqt.v4i1.1594.

10 Ahmad Dahlan, Pengantar Ekonomi Islam, (Jakarta: Prenadamedia Group,2019),hlm: 34. 
termasuk aktifitas ekonomi. Prinsip ini meletakkan dasar perilaku ekonomi dalam kontrol nilai ketuhanan sebagai basis nilai bahwa semua aktifitas manusia di dunia akan dimintai pertanggungjawaban pada hari akhir nanti. $^{11}$

Keterkaitan antara hukum dan kegiatan ekonomi tercermin dari terjadinya akad. Akad adalah proses yang penting di dalam proses kegiatan ekonomi, tanpa adanya akad proses trransaksi menjadi tidak sah, karena tidak adanya perjanjian di awal oleh kedua belah pihak. Proses kepemilikin adalah bentuk proses perpindahan hak milik berdasarkan transaksi, setelah terjadinya kesepakatan antara kedua belah pihak, untuk memindahkan hak milik kepada pihak kedua melalui pihak pertama, misalnya dalam transaksi jual beli, sewa-menyewa dan lain sebagainya. Dalam hal tersebut selalu ada keterkaitan antara aspek hukum dan ekonomi Islam.Sehingga kegiatan dalam ekonomi Islam digali dari hukum Islam itu sendiri, di dalam Islam kegiatan ekonomi dan hukum tidak dapat dipisahkan.

Sumber utama dalam hukum Islam adalah al-Qur'an, didalamnya menegaskan bahwa Nabi Muhammad diberi kewenangan untukmenjelaskan hukum-hukum yang ada dalam al-Qur'an dan dalam beberapa hal memberikan ketentuan hukum baru. Dengan demikian, Sunnah Rasul merupakan sumber kedua hukum Islam setelah al-Qur'an.Sunnah Rasul memberikan kesempatan kepada umat Islam untuk menemukan ketentuan-ketentuan hukum yang tidak disebutkan dalam al-Qur'an atau Sunnah Rasul secara jelas dengan jalan ijtihad.Dengan demikian, ijtihad dapat dipandang sebagai sumber ketiga hukum Islam. Hukum-hukum ijtihadiyah pada pokoknya bersumber kepada qiyas dan pertimbangan kepentingan dan kemaslahatan masyarakat $^{12}$. Di antara yang akan mendatangkan kebaikan dan memenuhi 122-123

${ }^{11}$ Ridwan, Hukum Ekonomi Syariah di Indonesia, (Purwokerto: STAIN Press, 2016), hlm:

12 Muhammad Yusri Yusof @ Salleh dan Mohd Anuar Ramli, “Kearifan Tempatan Dalam Adat Kematian Masyarakat Melayu Dari Perspektif Uruf: Local Wisdom in Death Customs 
kepentingan masyarakat adalah mengukuhkan berlakunya 'urf yang tidak bertentangan dengan nash al-Quran dan Sunnah Rasul. ${ }^{13}$

Masyarakat selalu mengalami perubahan dan perkembangan yang tentu saja akan berpengaruh kepada adat istiadat mereka ${ }^{14}$. Kalau hukum Islam dirumuskan berdasarkan adat kebiasaan tersebut, sedangkan adat itu mengalami perubahan, maka dengan berubahnya adat, hukum juga mengikuti $^{15}$. Perubahan hukum Islam dimaksud, bukanlah sekedar perubahan, akan tetapi harus dilakukan dengan usaha maksimal, yang disebut pembaharuan hukum Islam dengan menggunakan ijtihad sebagai sarananya. Dalam kaitannya dengan hukum Islam sebagai hukum Allah Swt, walaupun memungkinkan untuk mengalami perubahan melalui upaya pembaharuan hukum Islam, namun hukum-hukum yang berlandaskan kepada 'urf ini, juga adalah hukum Islam, karena Islam menghargai dan sangat memperhatikan manusia baik individu maupun masyarakat. 'Urf termasuk salah satu dalil hukum dalam Islam. ${ }^{16}$

\section{Penerapan urf dalam ekonomi Islam}

Di atas telah diketahui bahwa al-'âdah almuhakkamah, pada dasarnya merupakan adatkebiasaan manusia yang sesuai dengan syari'atIslam, sehingga oleh karenanya hukum dari adattersebut sesuai dengan dalil syar'i yang menjadi rujukan.

Among Malay Community from the 'URF Perspective," Journal of Fatwa Management and Research, 8 Juli 2020, 29, https://doi.org/10.33102/jfatwa.vol21no1.303.

${ }^{13}$ Fitra Rizal, Penerapan 'Urf sebagai Metode dan Sumber Hukum Ekonomi Islam', Al-Manhaj: Jurnal Hukum dan Pranata Sosial Islam, Vol. 1, No. 2 Juli 2019: 171-172

14 Zulkarnain Dali, "Hubungan Antara Manusia, Masyarakat, dan Budaya Dalam Perspektif Islam,” Nuansa 9, no. 1 (10 Juni 2016): 8, https://doi.org/10.29300/nuansa.v9i1.373; Moh Dahlan, "Hubungan Agama dan Negara Di Indonesia,” Analisis : Jurnal Studi Keislaman 14, no. 1 (2014): 25, https://doi.org/10.42042/analisis.v14i1.635.

15 Yesi Puspitasari, "Tradisi Pengasuhan Anak Kembar Secara Terpisah dalam Perspektif 'URF (Studi Kasus Di Desa Renah Kurung Kecamatan Muara Kemumu Kabupaten Kepahiang)” (undergraduate, IAIN Curup, 2019), 76, http://e-theses.iaincurup.ac.id/546/; Agung Setiyawan, "Budaya Lokal Dalam Perspektif Agama: Legitimasi Hukum Adat ('Urf) Dalam Islam," ESENSIA: Jurnal Ilmu-Ilmu Ushuluddin 13, no. 2 (22 Juli 2012): 238, https://doi.org/10.14421/esensia.v13i2.738.

${ }^{16}$ Galuh Nashrullah Kartika Mayangsari Rofam, Penerapan Konsep 'Urf dalam Kitab Sabilal Muhtadin, al-iqtishadiyah, Volume: IV, Nomor I, Juni 2018,hlm:7-8 
Contohnya dalam perbankan Islam, akad atau transaksi hutang piutang pada dasarnya adalah tidak wajib. Perintah Allah Swt dalam Surat Al-Baqarah ayat 282 pada dasarnya bukan perintah wajib, melainkan perintah sunnah yang artinya: 'Hai orang-orang yang beriman, apabila kamu bermua'amalah tidak secara tunai untuk waktu yang ditentukan, hendaklah kamu menuliskannya.’”

Dalam tafsir Jalain disebutkan, tujuannya adalah sebagai tanda bukti dan supaya tidak terjadi perselisihan di antara kedua belah pihak. Urf di Perbankan Islam adalah setiap akad tabungan atau hutang piutang adalah wajib dicatat karena untuk menghindari adanya kerugian di salah satu pihak. Karena syariat Islam mengajarkan setiap transaksi yang dilakukan oleh dua pihak haruslah tidak saling merugikan atau membahayakan salah satunya Nabi bersabda:'’Tidak boleh merugikan diri sendiri dan tidak boleh pula merugikan orang lain’’.

Hadist inilah yang menjadi prinsip muamalah dalam Islam.Dengan prinsip ini maka 'Urf perbankan Islam yang mewajibkan pencatatan dalam setiap transaksi dengan tujuan merugikan salah satu pihak adalah sesuai dengan ajaran Islam.Sehingga pencatatan tersebut tidak hanya wajib menurut perbankan tetapi wajib menurut hukum Islam. ${ }^{17}$

Contohlain 'urf' dalam ekonomi Islam adalah, dalam transaksi jual beli di pusat perbelanjaan modern dan transaksi yang berbasis online tanpa mengucapkan shighat (ucapan saya jual-saya beli). Apabila menggunakan literatur fiqh klasik maka jual beli seperti ini tidaklah sah karena tidak mengucapkan shighat (ucapan) jual beli yang jelas melainkan menggunakan isyarat atau tanda. Contoh isyarat atau tanda yang digunakan oleh penjual adalah meletakkan barang-barang/memajang gambar barang dengan label harga (offline/online)yang hendak dijual sedangkan untuk pembeli dengan cara mengambilnya dan membayarnya di kasir atau dengan cara transfer. Atau bahkan hanya memencet tombol

${ }^{17}$ Nasrulloh, Hukum Adat dan Penerapannya dalam Ekonomi Islam, Jurnal Al-Munqidz 
'’OK’, di HP. Seperti gojek, gofood, dan sebagainya. jual beli tersebut sudah menunjukkan kerelaan dari kedua belah pihak yang secara substantif sudah memenuhi prinsip dasar dalam akad jual beli. Dan jual beli tersebut boleh dilakukan berdasarkan 'urf atau kebiasaan masyarakat pada saat ini.

Dalam fiqh muamalah semestinya shighat merupakan hal yang menjadi rukun jual beli yang harus dipenuhi.seharusnya penjual berkata,"Saya jual barang ini kepada Andadengan harga sekian", lalu pembeli harus menjawab dengan lafadz,"Saya beli barang inidengan harga sekian, tunai" ${ }^{18}$. Namun akad dengan lafadz ini nyaris tidak digunakan oleh kebanyakan orang di masa sekarang.Tetapi secara substantif akad tersebut sudah memenuhi prinsip dasar dalam transaksi (akad) karena sudah adanya kerelaan kedua belah pihak dan keharusan dari akibat hukum yang timbul dari transaksi tersebut juga didasarkan atas tuntutan yang telah disepakati mereka bersama.Hal ini sudah sesuai dengan firman Allah (Q.S.AN-Nisa’: 29). "Hai orang-orang yang beriman, janganlah kamu saling memakan harta sesamamu dengan jalan yang batil, kecuali dengan jalan perniagaan yang berlaku dengan suka sama-suka di antara kamu’' Nabi Muhammad Saw juga bersabda "Sesungguhnya jual-beli itu haruslah dengan saling rela/ridha"(HR. Ibn Majah)”

Hal ini juga sudah sesuai dengan kaidah fiqh dalam bermuamalah yaitu:

$$
\text { الاصل في العقد رضى المتعا قدين و نتيجته ما التزماه با لتعا قد }
$$

' 'Hukum asal dalam transaksi adalah keridhaan kedua belah pihak yang berakad hasilnya adalah berlaku sahnya yang di akadkan,"19

Berdasarkan penjelasan diatas dapat dipahami bahwa setiap transaksi jual beli harus dilakukan dengan kerelaan oleh kedua belah

Volume 2, Edisi 2, Juli 2013

18 M. Ikhfan, “Tradisi Mitoni dalam Perspektif Hukum Islam (Studi Kasus di Desa Laren Kecamatan Bumiayu Kabupaten Brebes),” 43.

${ }^{19}$ Djazuli, Kaidah-Kaidah Fikih, ( Jakarta: Kencana,2006),hlm: 130 
pihak.Pada mulanya, shighat haruslah berupa ucapan (saya jual) dari penjual dan ucapan pembeli (saya beli).Namun kebiasaan kegiatan transaksi ekonomi modern hari ini ( 'urf) merubah segalanya menjadi lebih mudah.

\section{Kesimpulan}

'Urf menempati posisi yang penting dalam penetapan hukum. Hal ini karena 'urf menjadi kebiasaan yang berlaku di masyarakat secara membudaya di tengah-tengah masyarakat. Oleh karena itu, adat dan 'urf menjadi pertimbangan dalam menetapkan hukum yang telah dirumuskan menjadi kaidah umum, yaitu: al-adah muhakkamah dan al-Tsabit bi al-urfi ka al-Tsabit bi al-nash.

Keterkaitan antara hukum dan kegiatan ekonomi tercermin dari terjadinya akad. Akad adalah proses yang penting di dalam proses kegiatan ekonomi, tanpa adanya akad proses trransaksi menjadi tidak sah, karena tidak adanya perjanjian di awal oleh kedua belah pihak.Sehingga kegiatan dalam ekonomi Islam digali dari hukum Islam itu sendiri, di dalam Islam kegiatan ekonomi dan hukum tidak dapat dipisahkan.

'Urf dalam transaksi ekonomi sekarang ini adalah jual beli di pusat perbelanjaan modern dan transaksi yang berbasis online tanpa mengucapkan shighat (ucapan saya jual-saya beli). Apabila menggunakan literatur fiqh klasik maka jual beli seperti ini tidaklah sah karena tidak mengucapkan shighat (ucapan) jual beli yang jelas melainkan menggunakan isyarat atau tanda. Contoh isyarat atau tanda yang digunakan oleh penjual adalah meletakkan barang-barang /memajang gambar barang dengan label harga (offline/online) yang hendak dijual sedangkan untuk pembeli dengan cara mengambilnya dan membayarnya di kasir atau dengan cara transfer. jual beli tersebut sudah menunjukkan kerelaan dari kedua belah pihak dan secara substantif sudah memenuhi prinsip dasar dalam akad jual beli. Dan jual beli tersebut boleh dilakukan berdasarkan 'urf atau kebiasaan masyarakat pada saat ini. 


\section{DAFTAR PUSTAKA}

Bisri, Hasan, Model Penelitian Fiqh, Bogor: Prenada Media, 2003

Dahlan, Moh. "Hubungan Agama Dan Negara di Indonesia.” Analisis : Jurnal Studi Keislaman 14, No. 1 (2014): 1-28. Https://Doi.Org/10.42042/Analisis.V14i1.635.

Dali, Zulkarnain. "Hubungan Antara Manusia, Masyarakat, Dan Budaya Dalam Perspektif Islam.” Nuansa 9, No. 1 (10 Juni 2016). Https://Doi.Org/10.29300/Nuansa.V9i1.373.

Dahlan, Ahmad, Pengantar Ekonomi Islam, Jakarta: Prenadamedia Group,2019

Djazuli, Kaidah-Kaidah Fikih, Jakarta: Kencana,2006

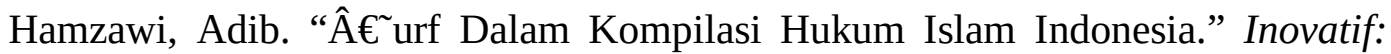
Jurnal Penelitian Pendidikan, Agama Dan Kebudayaan 4, No. 1 (2 Februari 2018): 1-27.

M. Ikhfan, Turfaulmali. “Tradisi Mitoni Dalam Perspektif Hukum Islam (Studi Kasus Di Desa Laren Kecamatan Bumiayu Kabupaten Brebes).” Skripsi, Iain Purwokerto, 2019. Http://Repository.Iainpurwokerto.Ac.Id/6573/.

Mohammad,Mufid, Ushul Fiqh Ekonomi Dan Keuangan Kontemporer, Jakarta: Prenadamedia Group,2016.

Mun'im Saleh, Abdul, Hubungan Kerja Usul Al-Fiqh Dan Al-Qawaid Al-Fiqhiyah Sebagaimetode Hukum Islam, Yogyakarta: Nadi Pustaka, 2012

Nashrullah, Galuh Kartika Mayangsari Rofam, Penerapan Konsep 'Urf Dalam Kitab Sabilal Muhtadin, Al-Iqtishadiyah, Volume: Iv, Nomor I, Juni 2018

Nasrulloh, Hukum Adat dan Penerapannya dalam Ekonomi Islam, Jurnal Al-Munqidz Volume 2, Edisi 2, Juli 2013

Nasrun, Haroen, Ushul Fiqh 2, Jakarta: Logos,2001

Puspitasari, Yesi. “Tradisi Pengasuhan Anak Kembar Secara Terpisah Dalam Perspektif 'Urf (Studi Kasus Di Desa Renah Kurung Kecamatan Muara Kemumu Kabupaten Kepahiang).” Undergraduate, Iain Curup, 2019. Http://E-Theses.Iaincurup.Ac.Id/546/. 
Rofam, Galuh Nashrullah Kartika Mayangsari. "Penerapan Konsep 'Urf Dalam Kitab Sabilal Muhtadin (Kajian Terhadap Pemikiran Muhammad Arsyad Al-Banjari).” Al Iqtishadiyah Jurnal Ekonomi Syariah Dan Hukum Ekonomi Syariah 4, No. 1 (7 Desember 2018): 1-19. Https://Doi.Org/10.31602/Iqt.V4i1.1594.

Rufaida, Arini. “Tradisi Begalan Dalam Perkawinan Adat Banyumas Perspektif 'Urf." Undergraduate, Universitas Islam Negeri Maulana Malik Ibrahim, 2011. Http://Etheses.Uin-Malang.Ac.Id/1420/.

Ridwan, Hukum Ekonomi Syariah Di Indonesia, Purwokerto: Stain Press, 2016

Rizal, Fitra, Penerapan 'Urf Sebagai Metode Dan Sumber Hukum Ekonomi Islam', Al-Manhaj: Vol. 1, No. 2 Juli 2019

Salleh, Muhammad Yusri Yusof @, Dan Mohd Anuar Ramli. "Kearifan Tempatan Dalam Adat Kematian Masyarakat Melayu Dari Perspektif Uruf: Local Wisdom In Death Customs Among Malay Community From The 'Urf Perspective." Journal Of Fatwa Management And $\begin{array}{lllll}\text { Research, } & 8 & \text { Juli 21-37. }\end{array}$ Https://Doi.Org/10.33102/Jfatwa.Vol21no1.303.

Setiyawan, Agung. "Budaya Lokal Dalam Perspektif Agama: Legitimasi Hukum Adat ('Urf) Dalam Islam.” Esensia: Jurnal Ilmu-Ilmu Ushuluddin 13, No. 2 (22 Juli 2012): Https://Doi.Org/10.14421/Esensia.V13i2.738.

Syarifuddin, Amir, '’Ushul Fiqh 2'’, Jakarta: Logos, 1999 